\title{
Organized Labour, Democracy and Good Governance in Nigeria, 1999-2007
}

\author{
Okonkwo C. Eze $^{1}$ \& Uchenna G. Chinwuba ${ }^{1}$ \\ ${ }^{1}$ Department of History and Diplomatic Studies, Federal University Wukari, Wukari, Nigeria \\ Correspondence: Okonkwo C. Eze, Department of History and Diplomatic Studies, Federal University Wukari, \\ PMB 1020, Katsina-Ala Road, Wukari, Taraba State, Nigeria. Tel: 234-80-3686-7099; 234-80-8182-1149. \\ E-mail: okochriseze@gmail.com
}

Received: December 13, 2014 Accepted: January 11, 2015 Online Published: February 27, 2015

doi:10.5539/jpl.v8n1p149

URL: http://dx.doi.org/10.5539/jpl.v8n1p149

\begin{abstract}
This paper intends to investigate the changing role of labour from that of a union to a movement that has come to champion the course of democracy and sustain good governance in Nigeria. This new role has generated a lot of debate and controversy among labour activists, political class as well as the general public. The 1999 bourgeois constitution of Nigeria not only skewed political activities in favour of politicians but also assigned a narrow function to labour in a liberal democracy that emphasizes popular participation and negotiation of interests. The Peoples Democratic Party (PDP) led by Obasanjo having demonstrated a penchant not brook opposition skillfully stifled the opposition through juicy appointments and award of fat contracts to some leading members of the opposition. Such a development was not just antithetical to democracy and good governance as its corollary but also tended to turn Nigeria into a one-party dictatorship. The creation of a myriad of weak and unviable political parties later was no more than a ploy to consolidate the PDP rulership of the country in an age where neither the Legislature nor the Judiciary has willingly risen to the responsibility of checking the excesses of the executive. This development has transformed labour from being a union concerned with the welfare of its membership to a movement poised to deepen and expand the content of democracy and good governance. The paper hopes to fill the gap in our knowledge of the enduring government-labour interface during the Obasanjo's second era. It avers that labour has through its strikes and mass appeal, brought some influences to bear on government's anti-people, pro-rich, and policies and practice considered obnoxious.
\end{abstract}

Keywords: labour, democracy, good governance, strikes and deregulation

\section{Theoretical Framework}

This work adopts the elite theory which attempts to explain the role of elites in democracy and governance. The political elites have tendered to take advantage of their access to political power to embark on unbridled primitive accumulation of wealth at the expense of the working poor. Because as they control the structures of the state, the latter's interests have become synonymous with theirs. It has been opined that "the fact that Nigeria is oscillating between democratic stagnancy and governance backwardness is reflexive of elites' pursuit of personal aggrandizement and promotion of egocentrism rather than altruistic policies, that are nationalistic and 'peoplecentric' in nature” (Note 1). This development alienated the working poor hence they had had to coalesce and synergize with the civil society groups to checkmate the powers of the elites in a democracy that advocates participation, accountability, transparency and fairplay. The role of labour in this context is to strengthen and deepen democracy as a means of ensuring good governance; a hallmark of democracy.

\section{Introduction}

The exclusion of labour from Nigerian politics has deservedly generated active debates amongst scholars, political class and other commentators. The bourgeois constitution of Nigeria would appear to assign a narrow function to labour in a liberal democracy which emphasizes grassroot participation, negotiation of interests, and interactivity. In addition, "the dividing line between economics and governance is very blurred and ... the logic which propels state's constant interference in labour matters equally dictates the need for trade unions to take active interest in...politics" (Note 2). The fact that it is at the political realm that decisions affecting the economic wellbeing of labour membership are taken justifies its involvement in politics. This is again because there are very strong linkages between democracy, good governance and labour’s economic wellbeing. 
As has been pointed out by Owei Lakemfa et al "the labour movement is wedded to democracy. Its bitter experiences under military dictatorship including being banned thrice, taught it that there is no better system today than a democratic one. It is therefore in labour's enlighten interest to defend democracy, deepen its content and expand its frontiers" (Note 3). It need be noted that Nigeria's democratic experiment so far appears to represent an era when the hope for a robust economy, responsible and responsive governance is misplaced. The road to democracy and good governance has been tortuous and rigorous as the military wanted to perpetuate itself in power. The military background of President Olusegun Obasanjo did not seem to promote the ideals of democracy during the period under investigation, Labour, as the driver of change committed the pro-poor policies provided the missing link in the efficiency equation for good governance in Nigeria. Organized labour has used various methods and approaches such as civil voter advocacy, monitoring elections, protests and strikes to deepen democracy and ensure good governance. This paper aspires to provide insights into the influence of labour in enriching the contents and course of democracy and good governance in Nigeria.

\section{Conceptual Clarifications}

In order to establish a firm grasp of the subject matter of this discourse, it is worthwhile to attempt a definition of each of the operational words. This is all the more necessary to establish the linkages between labour, democracy and good governance.

\subsection{Labour}

The term labour has not given itself to one generally accepted definition. In other words, it has no settled meaning as this is elastic. For some people, "labour is seen as the source of all wealth" (Note 4). In the opinion of E. Toyo, labour or trade unions "are organizations of an under-privileged class for class struggle in a society characterized by privilege.... The trade unions are organizations of the underdog in modern production and service activities. These underdogs are called employees, wage workers or salaried workers” (Note 5). Labour is, therefore, an umbrella organization of all workers whose only source of subsistence is the sale of their labour power. J.A.M. Audi would appear to agree no less with this position when he argued that "trade unionism all over the world emerged for improving the economic, living and working conditions of workers" (Note 6). In this paper, it is an organization of workers either in the pubic or private sector of the economy who sell their labour power whether mental or physical for wages and in the course of the discharge of their duties pool their energy and resources to seek permanent solutions to menacing socio-economic and political problems. Labour, in this discourse, refers to the Nigeria Labour Congress (NLC).

\subsection{Democracy}

Democracy is derived from two Greek words- 'demos' and ' $k r a t i a$ ' which connote 'the people' and 'the rule', respectively. Because it is a people-centred form of government, Abraham Lincoln has defined it as the "government of the people, by the people, for the people" (Note 7). According to the Webster's Encyclopedia Dictionary "democracy is a government in which the supreme power is invested in the people and exercised by them directly or indirectly through a system of representation usually involving periodically held free elecions" (Note 8). The people being referred to here are "the common people or the working people" (Note 9). According to Hannatu Musawa "democracy vis-à-vis good governance involves every stakeholder, particularly in the control of economic and political power in a way that inspires one's faith and commitment in the corporate reality of the nation" (Note 10). In the Nigerian context, democracy denotes nothing but minority rule where the minority dominates and exploits the masses and the working class. This is probably because government would seem to have subsumed the interests of the under-privileged majority in those of the few public office holders. This is a bourgeois democracy as it only grants symbolic participatory opportunities to the citizens while it serves the interest of the few public office holders. In the opinion of this author, democracy is a political contrivance which allows the mass of people to freely express their political will through a few elected representatives or individuals. This is the opposite of dictatorship, tyranny or autocracy. Democracy should advance equality not inequality in wealth and other life supporting amenities.

\subsection{Good Governance}

Governance, like any other political concept, has been subjected to varied definitions and explanations. In the opinion of P.O. Dozie, governance is "the totality of processes entitled in the exercise and management of the collective will of a people under a defined authority or constitution” (Note 11). It has also been seen to imply "the exercise of power by a person or a group of persons for the benefit of the populace" (Note 12). Alaba Ogunsanwo would appear to agree with this definition when he argued that "good governance is also responsible and responsive government since the welfare of the people ought to be the main purpose of the state and those who govern on its behalf" (Note 13). Good governance, therefore, has to do with those activities of the public 
office holders such as policy-making and implementation which ensure transparency, responsiveness, accountability, and efficient service delivery to enhance the quality of life of the governed. In a nutshell, it is not the process but the result of governance.

\subsection{Nexus between Labour, Democracy and Good Governance}

The assumption of office by Abdulsalam Abubakar as the new Head of State following the death of Sani Abacha on July 8, 1998 brought with it a sigh of relief to both the NLC and the Nigerian populace who had become visibly weary of military rule. The growing consciousness of democratic ideals would appear to have given impetus to the vehement resistance to the military dictatorship and the struggle to install democracy in the country. The repealing of the draconic Decree No4 of 1996 which had impeded the democratization of labour movement would appear to have re-positioned labour for more active role in the unfolding political process in the country. The new labour leadership under Adams Oshiomohole was to become an important institutional actor in Nigeria's democracy trajectory. It began by organizing a Presidential Parley between the two presidential candidates of the Peoples Democratic Party and the Alliance for Democracy/All Nigerian Peoples Party-Olusegun Obasanjo and Olu Falae, respectively. While Obasanjo was a former head of state, the latter was the Secretary to the Federal Military Government under Ibrahim B. Babangida and a chieftain of the 'subversive' National Democratic Coalition (NADECO).

Probably because the NADECO remained an opposition group against military rule, its "tag became associated with lack of patriotism and even subversion and its members were hounded,... and were disqualified from contesting the transition election" (Note 14) The eventual emergence of Obasanjo as the democratically elected 'civilian' president of Nigeria may have been due largely to his opponent's membership of the 'dreaded' NADECO. However, his regime was more or less a continuation of military dictatorship given his style of governance. There is no doubt that the "inability of the president to come to terms with what democratic governance meant and how to sustain the social contract made his pattern of leadership to be a lackluster one" (Note 15). Given Obasanjo's military and cultural backgrounds, opposition-'idakeji' in Yoruba language “conveys pejorative connotations and taint of disloyalty." (Note 16)

It is not unlikely that this thinking influenced, to a large extent, the Obasanjo government's attitude towards the organised labour. His government believed, as it were, that labour was but a "single-cause special interest group" (Note 17) that had nothing to do with governance. However, it is interesting to note that labour interests transcended narrow bread- and-butter activism to advocate democracy and good governance. In the words of E. Wogu, "trade unionism does not stop at the factory gate because for trade unions to meaningfully fight for and protect the interest of workers, it becomes imperative for workers under the umbrella of their unions to become actively involved in the national politics" (Note 18). It may, therefore, be plausible to state that "to the labour movement, good governance would translate to better welfares for their (sic) members especially in the public services" (Note 19).

Soon after the inauguration of the Third Republic on May 29, 1999 led by Obasanjo, labour took up measures to inspire salient values and elements of democracy and good governance. For instance, Oshiomhole noted on June 1, 1999 that "democracy in Nigeria would remain a problem if each time that military after exposing corrupt civilians were allowed to go despite their seeming corrupt practices" (Note 20). Labour's agitation for accountability and transparency was likely to have given rise to the emergence of the two anti-graft outfits- the Independent Corrupt Practices and other Related Crimes Commission (ICPC) and the Economic and Financial Crimes Commission (EFCC). This development was probably because "the country was ranked among the most corrupt and badly governed nations in the world, as such the Obasanjo administration inherited a nation state with a weak economic base" (Note 21). It can, therefore, be said that labour "constituted a significant and often potent constituency for responsive and accountable government" (Note 22) because through its promptings the two organs came into being.

However, both labour and public perceptions of these two institutions at their launch appear misplaced when a closer and hard look is taken at their anti-corruption activities. It is hardly doubtful that a number of 'Nigerian' factors conspired to distort their effectiveness in the laudable combat against corruption and financial crimes. A. Ikelegbe et al have forcefully argued that:

Their impact was stymied by the politics of the PDP and interference by the office of the Presidency - as clearly depicted in the way and manner former President Obasanjo used them to hound enemies and to achieve electoral objectives of disqualifying targeted candidates.... Corruption still undermined economic policies and the efficient functioning of state institutions, because 
anti-crime and corruption laws were not evenly applied to all Nigerians. Hence, the existence of a colony of the indicted and untouchables never subjected to scrutiny (Note 23).

There are doubts as to whether the anti-graft institutions have successfully prosecuted any political office holders and or retrieved their illegally acquired wealth, including perhaps, James Ibori, the former governor of Delta State, whose case of corruption has been proven by an English court. Although the two agencies may have not given a good account of themselves in the anti-corruption crusade, their creation was labour's contribution to deepen democracy and sustain good governance. Adams Oshiomhole appears to agree with this position when he opined that "since the beginning of this democratic process, there is no denying the fact that the Nigeria Labour Congress (NLC) had been a critical player in the national discourse and efforts at promoting good governance and public welfare" (Note 24). Labour, as the apostle of accountability, transparency and justice which formed a tripod for democracy and good governance to stand, ought to have brought some measure of influence to bear on the activities of the two anti-graft outfits. This failure seems to have put labour relevance into reverse.

\subsection{Labour, Elections Administration and Good Governance}

The 2003 general elections in Nigeria provided a litmus test for the organized labour and all the other stakeholders in the Nigerian project. The attempts by previous civilian regimes to conduct credible and generally accepted elections had always been characterized by manipulations of various kinds, falsification of election results and unbridled irregularities. The failure has been the bane of democratic experiments in the past and has made good governance a far cry. In order to forestall past experiences,

towards the 2003 general elections, the NLC was involved in a broad initiative to facilitate a transparent and peaceful polls that would usher in a civilian-civilian government. This included workers civic education and election monitoring (Note 25).

This move would appear to have enjoyed unbounded support from a number of pro-democracy groups such as the Campaign for Democracy (CD), Democratic Alternative (DA), Human Right Watch (HRW), Civil Liberty Organization (CLO), Committee for Defence of Democracy (CDD) and Friends of Minorities (FM). In defence of this position of labour, Oshiomhole once argued that "the urgent and sustainable task for the defence of civil democratic rule in Nigeria would not see labour play a fringe role but a frontal leadership role" (Note 26). In spite of this assertion, labour, sooner than later, bent over backwards not only to accept the results of the elections generally believed to have been manipulated but also canvassed their admission as a reflection of the electorate's will. This would appear to suggest that its leadership had been compromised.

Given the way elections were administered under the Obasanjo- led PDP government, it seems clear that he wanted to use democracy to destroy democracy. Elections conducted by his government were a mere ritual as they got worse successively. This development did not augur well for good governance which is grafted on democracy. In his own contribution to this wrong use of power of incumbency, Oshiomhole once more argues that "democracy without free and fair election is just an empty ritual that removes the people as the determinants of office-holders. Only Nigerians must determine who governs at all levels and never again should the will of the people be wantonly subverted through rigging" (Note 27). This can be said to be a mere rhetoric as the same labour leadership canvassed acceptance of the election results. The labour leadership lacked the savvg and moral courage to protest against the rape in democracy. In this case, labour did not give a good account of itself.

The 2007 general elections that brought into being the Yar'Adua/ Jonathan administration were generally believed to be a sham. The elections, according to Ikelegbe et al "witnessed a profound assault, rape, debasement, travesty and reversal of democratic norms" (Note 28). Again, Okwudiba Nnoli, has further argued that “... the elections of 1999, 2003 and 2007 failed woefully to meet even the most minimalist standards set by the petty bourgeois" (Note 29) It is all the more worrisome that global players stood by and watched helplessly an election that failed the test of a free and fair ballot. As has been observed "the international community appears less to impede the day-light rigging of elections and unconstitutional means of staying in power; ... it has contributed actively and even enthusiastically to the process" (Note 30). In his own reaction, Jean Herskovits accused Washington of conspiracy of silence over the elections in Nigeria because of her thirst for the latter's oil. In his words, "Nigeria elections last April were among the most seriously flawed in the country's history, thanks largely to the manipulations of the US-backed ruling party" (Note 31).

It is instructive to observe that both labour and civil society coalition (LASCO) not only rejected the results of the elections and the invitation to the presidential inauguration committee but also mobilized their membership for a protest against the 'coup' of 2007. This position was no more than a confidence-building measure intended 
to enhance its rating among its membership and the general public. Furthermore, it was believed that government formed on the basis of such flawed elections could hardly guarantee good governance. True to his military orientation, the Obsanjo government embarked on strong-arm practices of cracking down opposition or protesters through its security outfits. It is plausible to note for instance, that on 30 April, 2007, Emma. Ezeazu, the Secretary General of the Alliance for Credible Elections (ACE) was picked by the State Security Services (SSS) in an attempt to forestall the planed May protest against the April polls. In what looked like a panic measure, the Federal Government declared Monday the 28 and Tuesday the 29 May, 2007 public holidays to confuse the public with the LASCO's sit-at-home order to its members. There can be no doubt that flawed elections administration consisted one of the greatest challenges to sustenance of democracy which abnegated good governance and therefore socio-economic wellbeing of labour membership.

\subsection{Labour, Opposition Parties and the Quest for Good Governance}

The PDP government, on assumption of office on May 29, 1999, appeared in the least prepared to brook virile opposition; a dysfunction of democracy and good governance. The ruling party systematically undermined opposition parties through spurious inducements such as ministerial appointments and contracts; and probably infusion of schism into the latter. O Epia has succinctly argued that "through the weapon of appointment, the PDP broke the ranks of the other parties especially the Alliance for Democracy (AD) and (the) All Nigeria Peoples Party (ANPP). Members of the opposition parties who have held government appointment found it difficult to resist the temptation of belonging to the ruling PDP” (Note 32). It can be said that when such appointees were dragged into the web of the system of governance, they reneged on their responsibility to the citizens thereby creating a vacuum in the democratic process. The PDP led-government wanted to create a one party civilian dictatorship.

Labour appeared handicapped in the face of the drift towards a one-party system-agenda of the PDP-led government. This is because it had actively participated in the Otta Farm Dialogue which articulated the policies and programmes which the Obasanjo government was expected to pursue. It has further been argued that at Otta Farm Dialogue, labour, represented by A. Oshiomhole, S.O.Z. Ejiofor and A.A. Salam, proposed a Government of National Unity to the yet-to-be-formed civilian government. This was to forestall the winner-takes-all syndrome and ensure an inclusive government but certainly not a single party system. Contrary to labour expectation, Obasanjo was said to have asserted that one-party system was the remedy for Nigeria's underdevelopment (Note 33). This made democracy all the more elusive as it did not create room for a viable alternative which has been a veritable instrument for good governance. On the strength of this, it can be said that the significance of this development is in what was left out.

After having trampled upon the AD and ANPP, there was that fear that democracy has floundered hence the registration of many feeble and inconsequential political parties. The registration of 'too many' weak political parties by the Independent National Electoral Commission (INEC) can be said to be in an effort to further the dominance of the political space by the ruling PDP. Until the recent deregulation of twenty eight of them, the INEC had to grapple with enormous logistic and administrative problems from sixty three political parties during elections. Some of these parties were believed to be appendages of the ruling party. This goes to support the view "that many of the so-called political parties were actually 'sponsored' by the same set of politicians in the mainstream political parties." (Note 34). To Obasanjo- led government, "democracy... is limited to the formation of multiple political parties and the holding of periodic elections as the basis for the formation of governments." (Note 35) It may also be arguable that the factionalization and splintering of extant parties were at the prodding of the PDP-led government. For instance, Senator Yari Gandi of the ANPP once argued, among other things, that his faction left the party because "...it has been compromised. Under Don Etiebet, the ANPP became the mouthpiece of the PDP” (Note 36).

This development does not seem to encourage the growth of, and deepen the content of healthy democracy in the country. In this context, only the organized labour remained un-cowed and undaunted in the struggle to ensure good governance as well as sustain democracy. There is no doubt that “...there can't be democracy without a civil society; none without a media, and is almost unthinkable without vibrant opposition political parties, as there is no democracy without the state" (Note 37) It is in the context of this assertion that labour's role not just as the engine of national growth but also in the promotion of democracy and good governance can be appreciated. Labour, it should be noted, took up the gauntlet to advocate transparency, accountability and responsiveness on the part of the government. The advocacy was necessary because non-availability of these attributes not only alienated the people but also abnegated good governance which democracy was to translate to. Through demonstrations, strikes and pretests, labour has brought enormous influence to bear on the course of governance especially perhaps with particular reference to pro-poor and anti-people economic policies of the 
government.

It is plausible to state that all through Obasajno's reign, he had a running battle with the organized labour over the deregulation of the downstream sector of the oil industry. Ever since June 1, 2000 when the pump price of fuel was increased from $\$ 15$ to $\$ 30$ and later reduced to $\$ 22$ per litre, fuel price increase has become an issue of practical politics. On the eve of its exit from the Presidency in 2007, the Obasanjo government increased the price of fuel from $\$ 40$ to $\$ 70$ per litre but was reduced by U.M. Yar’Adua to $\$ 65$ per litre following a nation-wide protest by the coalition of labour and civil society coalition, LASCO (Note 38). Given this development, "the labour movement has remained a formidable rallying point for not only working people and subaltern groups, but also the vast majority of citizens who have come to identify the movement with progressive causes” (Note 39). The intermittent fuel price hike was intended to increase primitive accumulation of wealth by the politician-businessmen. The opposition from labour was to advance uninhibited access to the abundance of Nigeria's wealth by the masses who owned the nation. Undoubtedly the political elite had used the deregulation of the prices of petroleum products to exploit the mass of the people. As Nnoli puts it, such "exploitation of the masses is inimical to democracy" (Note 40).

The labour strikes appeared to have inspired the on-going probes, investigations and continuing alertness in the oil sector of the economy. Ever since the inception of the present democratic dispersion in Nigeria, nothing has elicited spirited opposition from labour as the continual fuel -price- hike Labour strikes have, undoubtedly, let off steam on the rot and corruption that characterized the deregulation exercises of the oil industry. Labour can, therefore, be said to have used protests, strikes and demonstrations to further the cause of the downtrodden and equitable distribution of the resources among the citizenry; a hallmark of democracy and good governance.

\section{Conclusion}

From the foregoing, it can be seen that in absence of vibrant and virile opposition parties, labour has assumed an increasingly important role in the Nigeria's democracy. This paper posits that labour should be seen as a viable partner in the effort to deepen democracy and good governance rather than as 'subversive' organization. This is because the welfare of the citizenry which forms part of its responsibility is also the ultimate goal of every government. Through strikes; a non-formal participation, labour has made democratic dictatorship increasingly difficult and advocated accountability, transparency and good governance the tripod stand upon which democracy rests.

This notwithstanding, the indigenous bourgeois class has systematically, through the misuse of state power excluded labour from active partisan politics and therefore weakened the movement as well as the masses of the country. On the other hand, for labour to have supported and canvassed same in 1999 for a man who was a part of the conspiracy that forcibly took over power from a constitutional government was an act of self-indictment. As a result of this, it was difficult for labour to forestall anti-people democracy foisted on Nigerians by the military politician.

\section{Notes}

Note 1. D.E. Arowolo et al, "Democracy, Political Participation and Good Governance in Nigeria" in International Journal of Development and Sustainability, Vol. 1. No. 3, December 2012, p. 4

Note 2. E. Wogu, "Labour and National Development in Nigeria”, A Paper presented at the $11^{\text {th }}$ Eni-Njoku Memorial Lecture held at the University of Nigeria, Nsukka on 20/7/12 p. 22

Note 3. O. Lakemfa et al, Nigeria: Balloting for Democracy? A Report of the 2003 General Elections (Abuja: Labour Election Monitoring Team (LEMT), 2003), p.1

Note 4. Quoted in W.J. Oyaide et al, “Transnational Cooperation and Development Prospects” 'A Paper presented at the Centre for Social, Cultural \& Environmental Research (CENSCER), University of Benin, Benin City on 10 Feb; 1983, p. 4.

Note 5. E. Toyo, “Labour Movement and Advance to Democracy in Nigeria” in O.E. Uya (ed) Civil Society and the Consolidation of Democracy in Nigeria, (Ibadan: Daybis Ltd, 2008), p.159

Note 6. J.A.M Audi “Strike as Labour Union Tool in Nigeria: Reflections on Trade Union Act, 2005” in Journal of Law and Service; The Publication of Realist Chamber Vol. 1 No 2 in Honour of Hon. Justice R.H. Cudjoe, Ahmadu Bello University, Zaria: 2009, p 110

Note 7. Quoted in I.N. Obasi, “Theories and Practice of Democracy in Africa” in J. I Onwoha et al,(eds) Contemporary Issues in Social Sciences, (Enugu: Acena Publishers, 1995), p. 23

Note 8. Webster New Explorer Encyclopedic Dictionary, USA Springfield, 2006 (ed) p.481 
Note 9. Toyo...p.155

Note 10. H. Musawa, “Good Governance As Panacea for Sustainable Democracy” in The Nation, Saturday September 13, 2004,p.9.

Note 11. Quoted in The Guardian, November 24, 1999, p.37

Note 12. N.C. Ejituwu, "Election Process and Governance: Election Rigging the USA and Nigeria” in O. Ogunba (ed) Governance and the Electoral Process: Nigeria and the United States of America,(Lagos: Panaf Press, 1997), p. 37

Note 13. A. Ogunsanwo, "Good Governance, Democracy and Civil Society "in O. Ogunba (ed) The Empowerment of the Civil Society in a Democracy: Nigeria and the United States of America; America Studies Association of Nigeria, (ILe-Ife Anchor Print Ltd, 2000), p.1

Note 14. O. Eminue "The Role of National Democratic Coalition in the Consolidation of Nigeria Democracy” in O.E. Uya....p.421.

Note 15. C.N. Ihediwa "Democracy and Autocratic: The Post Military State under Olusegun Obasanjo 1999-2003 in T Wuam, et al (eds) Obasanjo Second Era, 1999-2007, (Makurdi: Aboki Publishers, 2011), p.212.

Note 16. O. Eminue ... p 419

Note 17. Ibid... p. 419

Note 18. Wogu ... p. 22

Note 19. Ibid ... p. 23

Note 20. Quoted in C.C. Opata, "Labour Union and Sustenance of Democracy: Lesson from the Nigerian \& “American Experiences” in Journal of Liberal Studies, vol. 10 no 2 (UNN December 2002), p. 146

Note 21. W. O. Alli, "The Role of Pro-Democracy and Non-Governmental Organisations in the Growth of Democratic Ideals in Nigeria” in Ogunba (ed)... p 89.

Note 22. J. Obilikwu, “Obasanjo Administrative Banking Sector Reform: A Critical Assessment” in T. Wuam et al (eds) Obasanjo Second Era, ... p. 254.

Note 23. A. Ikelegbe et al, “The PDP and Governance in Nigeria, 1999-2007” in S. Odion-Akhaine, (ed), The Constitution: A Journal of Constitutional Development

(Lagos: Panaf Press, 2008), p. 57

Note 24. Quoted in Soji-Eze Fagbemi, “The Politics of Labour Law” in Tribune, April 18, 2005, p. 19

Note 25. Lakemfa et al, ... p.1

Note 26. Quoted in The Vanguard, Thursday, February 18, 1999, p.11

Note 27. Quoted in The Guardian, January 3, 2006, p. 64

Note 28. Ikelegbe et al ... p 38

Note 29. O. Nnoli; The Struggle for Democracy in Nigeria (Enugu: PACREP, 2011) p. 294.

Note $30 . \quad$ "New of Military Coups in Africa". http://www.currentanalyst:com/index.php/conflictregion/97-new-generation-of-militqary-coups-in-africa

Note 31. Quoted in Daily Sun, July 14, 2007, p.8

Note 32. O. Epia, "Where is the Opposition” in Thisday Thursday, august 19, 2003 p.11

Note 33. Oral Interviews with U.F. Ezeja, a one-time State Chairman, NLC, Enugu State Chapter, aged 50 years interviewed on 27 July, 2013.

Note 34. Deregistration of Political Parties; The Guardian Editorial, Thursday January 3, 2013, p. 14.

Note 35. Nnoli, p.231.

Note 36. Quoted in S. Odion-Akhaine, The Next Anarchy: A People's Analysis of Nigeria's Fourth Republic, (Lagos: Panaf, Press 2008), p. 59.

Note 37. New Generation of “Military Coups in Africa...” p.2.

Note 38. See O. Omojolomoju "Pump Price and Minimum Wage: Nigeria versus OPEC Countries". http//www.nationalmirroonlinenet/plugins/bannermanager p.2. 
Note 39. Wogu... pp 6-7.

Note 40. Nnoli, pp 230-231.

\section{Copyrights}

Copyright for this article is retained by the author(s), with first publication rights granted to the journal.

This is an open-access article distributed under the terms and conditions of the Creative Commons Attribution license (http://creativecommons.org/licenses/by/3.0/). 